\title{
Veno-arterial extracorporeal membrane oxygenation for short-term mechanical circulation support in adults with cardiogenic shock: a single centre experience
}

\author{
Robert Musiał ${ }^{1}$, Paweł Moncznik ${ }^{1}$, Paweł Śmiałek ${ }^{2}$, Jarosław Stoliński ${ }^{3}$, Jerzy Sadowski ${ }^{3}$, Rafał Drwiła ${ }^{4}$ \\ 'Department of Anaesthesiology and Intensive Therapy, John Paul II Specialist Hospital, Krakow, Poland \\ ${ }^{2}$ Medical University of Warsaw, Warsaw, Poland \\ ${ }^{3}$ Department of Cardiovascular Surgery and Transplantology, Jagiellonian University Medical College, John Paul II Specialist Hospital, \\ Krakow, Poland \\ ${ }^{4}$ Department of Anesthesiology and Intensive Care, Jagiellonian University Medical College, John Paul II Specialist Hospital, Krakow, Poland
}

\begin{abstract}
A bstract
Background: Patients suffering from cardiogenic shock, with no response to conventional therapy, may significantly improve when put on support devices such as extracorporeal membrane oxygenation (ECMO), which maintains systemic and pulmonary circulation, and decongests the heart. This publication presents authors' own experience in qualifying and treating patients with cardiogenic shock, with the use of veno-arterial (VA) ECMO modality.

Aim: The main goal of the study was to analyse factors influencing outcome of VA ECMO therapy in patients with cardiogenic shock. Survival data were compared for patients surviving treatment $(n=12,41 \%)$, and for patients who died while VA ECMO.

Methods: Retrospective study included all patients treated between February 2009, when ECMO was first used in the clinic, and March 2015. Of those, 29 patients were treated with VA ECMO for respiratory support. Mean patient age was 42 years; 19 (66\%) patients were male, and 10 (34\%) patients were female.

Results: Total in-hospital mortality rate was 59\% (17/29). No difference was observed as to patient age, sex, body height, mode of hospital admission, comorbidities or left ventricular ejection fraction at hospital admission, when comparing survivors and patients who died despite treatment. The following parameters were analysed: number of days on VA ECMO, troponin levels during first days from treatment onset, platelet transfusions, and duration of mechanical ventilation. No significant differences were observed between the groups. Surviving patients were significantly longer hospitalised $(p=0.016)$, including a longer stay in the intensive care unit $(p=0.03)$.

Conclusions: VA ECMO is an acceptable therapy for patients in a severe state of cardiogenic shock. In-hospital mortality rate was $59 \%$, and $41 \%$ patients (12 subjects) were successfully treated with VA ECMO in course of cardiogenic shock.
\end{abstract}

Key words: cardiogenic shock, extracorporeal life support, extracorporeal membrane oxygenation

Kardiol Pol 2016; 74, 12: 1477-1484

\section{INTRODUCTION}

Extracorporeal membrane oxygenation $(\mathrm{ECMO})$ is a modality of external life support. The system enables long-lasting circulatory or respiratory support or can totally take over respiratory function in patients hospitalised in intensive care units (ICU). Approximately 2-6\% patients develop cardiogenic shock after cardiosurgical procedures [1]. When haemodynamic instability persists despite maximal doses of inotropic agents, direct mechanical support of circulation needs to be considered. This procedure requires though a completed surgical intervention. Support systems such as ECMO decongest the heart while maintaining blood flow in both systemic and pulmonary 
circulation. The decision to stop intensifying pharmacological stimulation, and to apply mechanical support should be made before organ hypoperfusion caused by long-lasting low ejection fraction (EF) syndrome causes development of irreversible injury.

First attempt to use external pump for supporting or replacing heart and lungs took place in 1953 when Gibbon constructed a "lung-heart machine". For the first time, he successfully applied extracorporeal circulation, creating a cardiopulmonary bypass during the procedure of closing interatrial defect in a 18-year-old woman [2]. When application of extracorporeal circulation became feasible in the operating room, attempts were initiated to facilitate the use of similar methods in ICU. Long-term application became reality after Hill et al. [3] successfully used extracorporeal circulation for $72 \mathrm{~h}$ in adults, and described these procedures in 1972. Since then, an enormous technological progress occurred, and more advanced ECMO devices were constructed. The attempts to develop ECMO therapy intensified in 2009, during the AH1N1 epidemics, when veno-venous circuit (VV ECMO) was used to prevent critical organ hypoxia, and thus facilitated pharmacological treatment of the most severe infections. Since 1989, Extracorporeal Life Support Organisation (ELSO) has recorded ECMO treatment procedures in more than 33,000 neonates, 15,000 children and 13,000 adults [4]. Thanks to the presence of oxygenator and centrifugal pump, ECMO device may provide extracorporeal circulatory support both in pulmonary and in systemic circuit. The most important indication for ECMO therapy in adults with cardiac insufficiency is cardiogenic shock [4]. Other possible applications include low EF syndrome with hypotension, organ hypoperfusion demonstrating with oliguria and acidosis despite adequate fluid therapy and vascular bed filling. The device should be implanted in case of cardiogenic shock persisting despite adequate administration of inotropic and vasoactive drugs. Septic shock is an indication for ECMO therapy in veno-atrial (VA) configuration in many institutions [4]. Successful application of extracorporeal warming for VA $\mathrm{ECMO}$ in cases of accidental hypothermia was described in some centres [5-8]. Recently, there is a tendency to use VA ECMO as a treatment of choice for hypotermic patients [9-13]. Extracorporeal life support may be an effective treatment in patients developing cardiogenic shock due to drug poisoning, not responding to conventional therapy [14].

Not all patients requiring vital function support are eligible for ECMO therapy, which is contraindicated in cases of irreversible organ damage causing circulatory or respiratory insufficiency, massive haemorrhage, and in patients with contraindications to chronic heparinisation. In some centres, absolute contraindications to ECMO treatment include severe neurological damage, uncontrolled (disseminated) malignancy, patient age of over 80 years or comorbidity impeding recovery [15].

\section{METHODS \\ Study group}

The study was performer in accordance with regulations of Declaration of Helsinki. As it was a register study, where patient-identifying data was not collected and therapeutic process was not to be affected, application for approval from the local bioethical committee was not required. Permission for manuscript preparation was granted from the hospital's head manager. Study group included all consecutive patients treated at the Department of Anaesthesiology and Intensive Care, belonging to the Department of Cardiovascular Surgery and Transplantology, Jagiellonian University Medical College in Krakow. The included patients were treated with VA ECMO for cardiogenic shock. Excluded were 9 patients treated with VA ECMO due to accidental hypothermia. Study group comprised 29 patients, and the observation period was from January 2009 when ECMO was introduced in the department, to March 2015. Retrospective analysis included demographical data, mode of hospital admission, primary cause of initiating ECMO treatment, comorbidities, left ventricular EF (LVEF) at hospital admission, troponin profile under first 3 days of hospitalisation, duration of in-hospital stay, duration of stay in the ICU, duration of mechanical ventilation, deaths as well as complications of ECMO therapy.

In-hospital death was defined as decease of any cause occurring within 30 days from onset of ECMO therapy or after this period but during the same hospitalisation [16]. Renal insufficiency was diagnosed in patients having creatinine over $177 \mu \mathrm{mol} / \mathrm{L}[17]$.

\section{Therapy}

Femoral vessel access was most often performed in right or left groin, with venous inflow to pump by a 22-24 F cannula and return via a 19-21 F cannula (currently used are cannulas from Bioline Coating Maquet, Germany). Life supporting device included a Rotaflow Console REF 706037 (Maquet, Germany), Heater Unit HU 35 (Maquet, Germany) and an oxygenator (Permanent Life Support Set "Bioline-Coating", Maquet, Germany) with a set of cannulas. Femoral artery was accessed directly. Initial flow rate was set at $65 \mathrm{~mL} / \mathrm{kg} / \mathrm{min}$, and then adjusted so as to obtain oxygenation of mixed venous blood $\mathrm{SvO}_{2}$ of $60-70 \%$. $\mathrm{FiO}_{2}$ was set at $40-60 \%$ in order to obtain arterial blood saturation $\left(\mathrm{paO}_{2}\right)$ between $150 \mathrm{~mm} \mathrm{Hg}$ and $200 \mathrm{~mm} \mathrm{Hg}$ and carbon dioxide partial pressure $\left(\mathrm{paCO}_{2}\right)$ of 35-45 mm Hg. Activated coagulation time was kept at 160-200 s, controlled by continuous heparin infusion. Mean arterial pressure was maintained at $60 \mathrm{~mm} \mathrm{Hg}$.

Many patients required vasopressor therapy directly after operation (epinephrine, norepinephrine, dobutamine). Echocardiography was performed in all patients for assessment of LVEF. Haemoglobin concentration was maintained at $8 \mathrm{mg} / \mathrm{dL}$, with help of blood product infusions. Default platelet concentration was $>80,000 / \mathrm{mL}$. Continuous infusion of 
Table 1. Demographical data and patient characteristics in subgroups with respective comorbidities

\begin{tabular}{|lccc|} 
& Deceased & Survived & P \\
\hline Sex (male/female) & $12 / 5$ & $7 / 5$ & 0.4941 \\
Age & $42.0 \pm 15.51$ & $41.2 \pm 13.78$ & 0.7040 \\
Body weight & $76.6 \pm 17.77$ & $73.0 \pm 9.64$ & 0.0451 \\
Body height & $1.7 \pm 0.08$ & $1.7 \pm 0.08$ & 1.0000 \\
BMl & $27.9 \pm 5.90$ & $25.95 \pm 5.05$ & 0.6081 \\
AH (yes/no) & $7 / 10$ & $2 / 10$ & 0.1597 \\
DM type 2 (yes/no) & $3 / 14$ & $1 / 11$ & 0.4438 \\
MI (yes/no) & $7 / 10$ & $2 / 10$ & 0.1597 \\
PCl (yes/no) & $3 / 14$ & $1 / 11$ & 0.4438 \\
Emergency admission to hospital (yes/no) & $8 / 9$ & $10 / 2$ & 0.0641 \\
EF at admission to hospital (median) & $35.59 \pm 20.53(40)$ & $27.08 \pm 26.58(10)$ & 0.2449 \\
\hline
\end{tabular}

$\mathrm{AH}$ - arterial hypertension; BMI — body mass index; DM — diabetes mellitus; EF — ejection fraction; MI — myocardial infarction; $\mathrm{PCl}$ - percutaneous coronary interventions

fentanyl and midazolam was performed for analgo-sedation during salvage controlled mechanical ventilation (respiratory volume $6 \mathrm{~mL} / \mathrm{kg}$ ideal body mass, respiration frequency 10/min, PEEP $4 \mathrm{~cm} \mathrm{H}$ O). Antibiotics were administered after consultations with the team responsible for managing in-hospital infections.

\section{Statistical analysis}

Statistical analyses were performed using STATISTICA 10 PL software. Descriptive analyses were performed for selected variables, and presented on histograms. For quantitative variables, number and percentage were calculated for each subgroup, and presented on column graphs.

Logistic regression model was used for analysis of correlations between qualitative and continuous variables with patient deaths. Odds ratio (OR) with 95\% confidence interval (Cl) was calculated for each significant correlation. If logistic regression could not be applied, $\chi^{2}$ test was used.

Level of statistical significance was adopted for $p$ value lower than 0.05. Student's t test was used for comparison of two groups, and non-parametric Mann-Whitney test for comparison of variables of non-normal distribution [18].

\section{RESULTS}

Study group included 29 patients treated with VA ECMO, including 19 (66\%) males. Mean patient age was 42 years. Overall in-hospital mortality rate was 59\% (17/29).

Factors influencing survival of patients treated with VA ECMO were then analysed. For this purpose, outcomes were compared between survivors ( $\mathrm{n}=12 ; 41 \%$ ) and patients who died despite adequate extracorporeal membrane oxygenation therapy in VA configuration. Table 1 contains demographical data and general characteristics of subgroups, including comorbidities.
In 18 (62\%) patients, ECMO therapy was administered due to inability to stop extracorporeal circulation or after cardiosurgical procedures. The remainder 11 (38\%) patients required therapy due to a severe cardiogenic shock resulting from cardiac decompensation in course of cardiomyopathy or myocarditis.

Causes of ECMO therapy initiation after respective cardiosurgical procedures are presented in Figure 1.

No differences were observed between survivors and deceased patients as to age, sex, body height, hospital admission mode, comorbidities or left LVEF at hospital admission. Logistic regression analysis did not identify any correlations neither between qualitative and continuous variables nor between deaths and demographical data (Table 2) or cause for ECMO therapy initiation (Table 3). No significant correlation was observed between deaths and comorbidities (Table 4).

Analysis of surviving patients as compared to deceased ones involved Student's t-test or non-parametric Mann-Whitney test, for variables of non-normal distribution (Table 5). The investigated variables included number of days on VA ECMO therapy, troponin levels during first days of therapy, transfusions of platelet concentrates, and duration of mechanical ventilation. No significant differences were observed between the groups. The surviving group had significantly longer hospitalisations in ICU ( $p=0.03$; Fig. 2) and duration of in-hospital stay ( $p=0.016$; Fig. 3 ).

Both groups of patients treated with VA ECMO experienced complications. Those included thrombostatic perturbations with necessity of transfusing blood products ( $n=21,72 \%)$, liver failure $(n=19,66 \%)$, acute kidney injury necessitating continuous kidney replacement therapy ( $n=10,35 \%)$, and lower limb ischaemia ( $n=10,35 \%)$. Seven (27\%) patients developed cardiac tamponade and underwent re-thoracotomy. Four (14\%) patients required pleural 


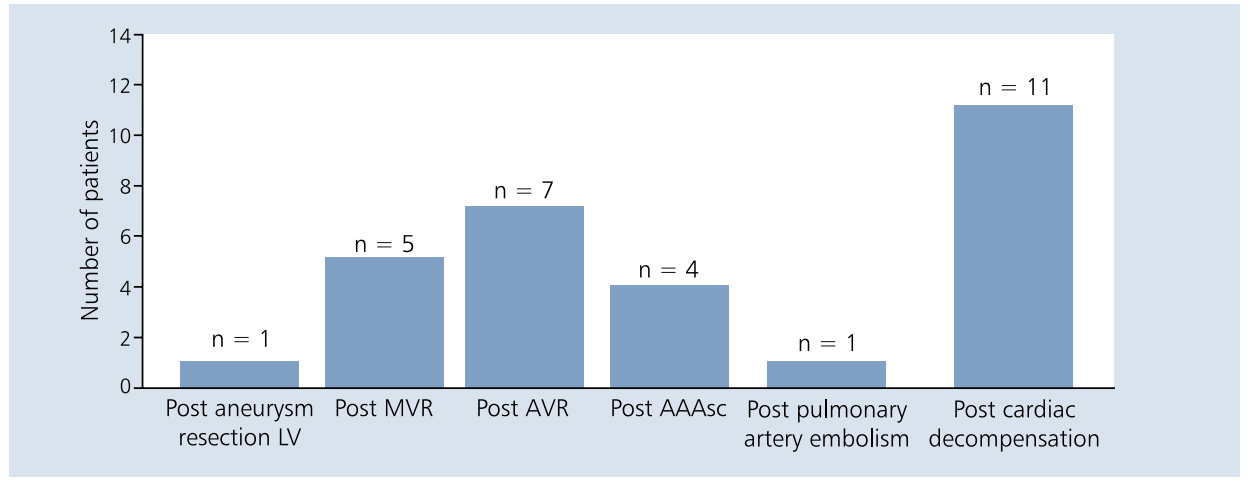

Figure 1. Causes of ECMO therapy following respective cardiosurgical interventions; AAAsc - aneurysm of ascending aorta; AVR - aortic valve replacement; LV — left ventricle; MVR — mitral valve replacement

Table 2. Logistic regression analysis of demographical characteristics influencing risk of patient death during VA ECMO therapy

\begin{tabular}{|lccc|} 
& OR & Cl & P \\
Sex & 0.6 & $0.1-4.6$ & 0.592 \\
Age & 1.0 & $0.1-1.1$ & 0.877 \\
Body weight & 1.0 & $1.0-1.1$ & 0.510 \\
BMl & 1.0 & $0.9-1.2$ & 0.350 \\
\hline
\end{tabular}

$\mathrm{BMI}$ — body mass index; $\mathrm{Cl}$ — confidence interval; $\mathrm{OR}$ — odds ratio

Table 3. Logistic regression analysis of risk factors for death during VA ECMO therapy (including indications for therapy)

\begin{tabular}{lccc|} 
& OR & Cl & P \\
\hline Post cardiac surgery & 4.6 & $0.9-24,4$ & 0.064 \\
Ischaemic cardiomyopathy & 0.8 & $0.2-4.4$ & 0.822 \\
Myocarditis & 0.6 & $0.1-4.3$ & 0.631 \\
MVR & 1.1 & $0.1-8.4$ & 0.945 \\
AVR & 6.0 & $0.6-65.0$ & 0.123 \\
AAAsc & 2.4 & $0.2-29.0$ & 0.483 \\
Pulmonary artery embolus & 0.2 & $0.0-5.9$ & 0.414 \\
Circulatory decompensation & 0.4 & $0.1-2.1$ & 0.265 \\
\hline
\end{tabular}

AAAsc — aneurysm of ascending aorta; AVR — aortic valve replacement; $\mathrm{MVR}$ - mitral valve replacement; $\mathrm{Cl}$ — confidence interval; OR — odds ratio

Table 4. Logistic regression analysis of risk factors for death during VA ECMO therapy (comorbidities)

\begin{tabular}{lccc|} 
& OR & $\mathbf{C l}$ & $\mathbf{P}$ \\
\hline Arterial hypertension & 3.5 & $0.5-23$ & 0.172 \\
DM type 2 & 2.4 & $0.2-28$ & 0.483 \\
Previous MI & 3.5 & $0.5-23$ & 0.172 \\
Status post PCI & 2.4 & $0.2-29$ & 0.483 \\
Elective hospitalisation & 0.2 & $0.03-1.2$ & 0.058 \\
Dyslipidaemia & 2.7 & $0.4-18$ & 0.279 \\
IABP on admission & 0.6 & $0.1-3.4$ & 0.562 \\
\hline
\end{tabular}

$\mathrm{Cl}$ - confidence interval; DM - diabetes mellitus; IABP — intraaortic balloon pump; $\mathrm{MI}$ - myocardial infarction; OR — odds ratio cavity drainage, and in $3(10 \%)$ intracavitary electrodes were placed. There were no significant correlations between these complications and patient deaths (Table 6).

Positive blood cultures were obtained in 8 (28\%) patients. Surviving patients were significantly longer hospitalised, and had longer periods in ICU, which increases markedly risk of infection.

Therapy using VA ECMO was effective in 12 (41\%) of 29 patients in severe cardiogenic shock. Decision to start ECMO treatment was in each case related to lack of clinical improvement and inefficacy of adequate standard therapeutic measures. Three (10\%) patients after successful ECMO therapy were discharged home, 7 (24\%) were transferred to cardiology departments for further therapy, and 2 (7\%) were discharged to sanatoria for rehabilitation.

\section{DISCUSSION}

Veno-arterial ECMO is an accepted therapeutic modality for patients in severe cardiogenic shock. In-hospital mortality rate was 59\% in VA ECMO-treated patients in the presented study. Thus, $41 \%$ patients receiving this therapy successfully recovered from a severe cardiogenic shock. Those were, among others, patients after cardiosurgical interventions or patients who could not be put on extracorporeal circulation. Decision to initiate ECMO treatment following cardiac surgery was in most cases related to inability to stop extracorporeal circulation after the procedure, and inotrope medication was ineffective. Among these patients, 18 (62\%) had ECMO implanted directly after surgical procedure, before transfer to ICU. Patients who developed cardiogenic shock not related to cardiac surgery were put on ECMO when vasopressor doses were as follows: epinephrine $8-10 \mu \mathrm{g} / \mathrm{min}$, norepinephrine 6-14 $\mu \mathrm{g} / \mathrm{min}$, dobutamine 5-10 $\mu \mathrm{g} / \mathrm{kg} / \mathrm{min}$. In 9 (31\%) patients ECMO was implanted less than $24 \mathrm{~h}$ from admission to ICU. In 2 subjects, therapy was initiated on respectively day 3 and day 7 from ICU admission, following unsuccessful attempts at haemodynamic stabilisation and application of intraaortic balloon pump. Both patients experienced a rapid 
Table 5. Variables affecting survival of VA ECMO-treated patients during hospitalisation in ICU

\begin{tabular}{|lccc|} 
& Deceased & Survived & P \\
\hline Number of days on ECMO & $8.18 \pm 7.75(5)$ & $11.83 \pm 7.16(11)$ & 0.1171 \\
IABP on admission & $0.24 \pm 0.44(0)$ & $0.33 \pm 0.49(0)$ & 0.6788 \\
Troponin level, day 1 & $14.00 \pm 29.09(1.69)$ & $2.57 \pm 3.23(0.74)$ & 0.3238 \\
Troponin level, day 2 & $20.78 \pm 33.71(2.66)$ & $2.80 \pm 3.40(1.59)$ & 0.2803 \\
Troponin level, day 3 & $12.70 \pm 18.79(2.425)$ & $2.07 \pm 2.35(1.33)$ & 0.1890 \\
Transfusion of platelet concentrates & $9.12 \pm 11.17(4)$ & $7.67 \pm 6.98(4)$ & 0.7770 \\
Number of days on mechanical ventilation & $10.94 \pm 11.04(5)$ & $13.58 \pm 12.70(10)$ & 0.498540 \\
Number of days in ICU & $14.24 \pm 15.41(5)$ & $24.75 \pm 12.49(27.5)$ & 0.0301 \\
Number of days in hospital & $20.59 \pm 27.94(9)$ & $35.42 \pm 16.53(32)$ & 0.0161 \\
\hline
\end{tabular}

Values are expressed as mean \pm standard deviation as well as median (in parentheses); ICU — intensive care unit; IABP — intraaortic balloon pump

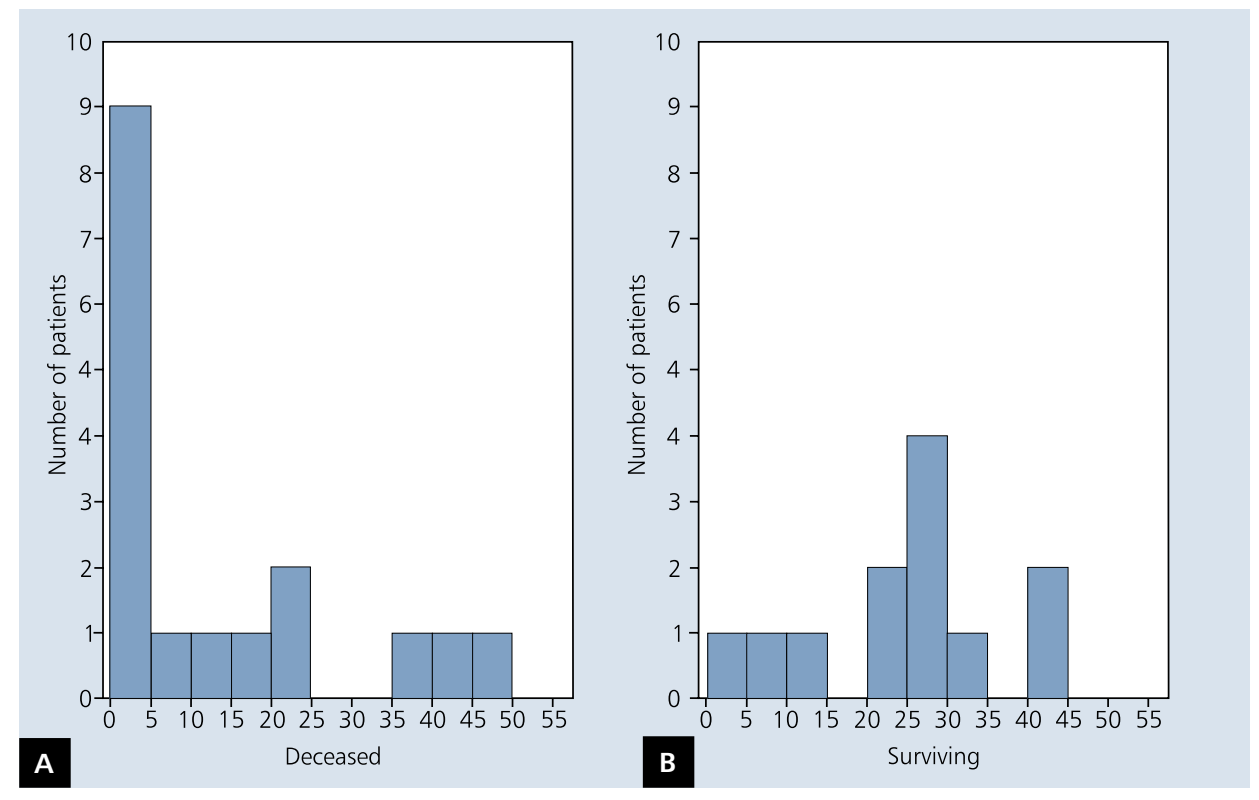

Figure 2. Duration of stay in intensive care unit (ICU) for patients deceased (A) and patients surviving (B) during ECMO therapy

decrease in $\mathrm{EF}$ by $5-10 \%$ and required increased doses of vasopressors, which triggered the decision to start extracorporeal support.

In the presented study, authors describe own experience in VA ECMO therapy of patients in a severe state of cardiogenic shock. The system can be applied using a central access but also by peripheral vascular access. In authors' institution, peripheral access is preferred given the necessity of anticoagulation treatment due to haemostatic disorders and because of infection risk. The study showed that surviving patients were much longer hospitalised, and treated in ICU, which explains high costs of therapy in this group. Technical characteristics and clinical profile of ECMO circulatory and respiratory support contribute to multitude of treatment indications. In the presented study, a modern mobile system was applied, enabling relocation of device together with the patient and continuation of treatment for a longer period. The device demonstrates a good steerability and flexible respiratory and circulatory support. Therapy with ECMO was successfully applied for recovery, before heart transplantation or by default in patient in accidental hypothermia [19]. Promising results were also described in ECMO treated patients with cardiac failure after medicinal poisoning [14]. Aubron et al. [20] point out that bleeding and coagulopathy are the most common complications in ECMO-treated patients, apart from neurological, vascular and infectious complications. These are also major risks of death in this patient population. Second most common group of complications includes haematogenic infections [20]. In the presented study, 72\% patients experienced bleeding and coagulopathy, being the two most common 


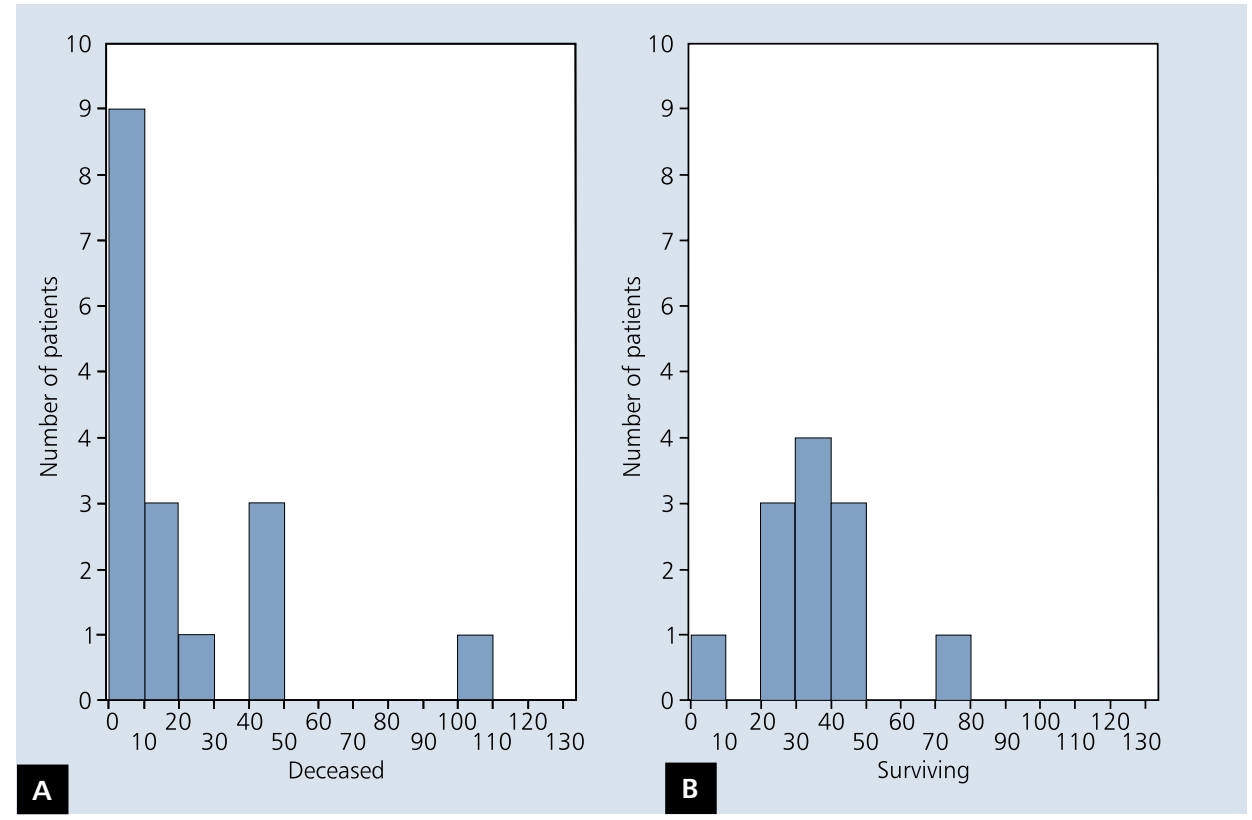

Figure 3. Duration of stay in hospital for patients deceased (A) and patients surviving (B) during ECMO therapy

Table 6. Logistic regression analysis of risk factors for death during VA ECMO therapy (in intensive care unit)

\begin{tabular}{|lccc|} 
& OR & CI & P \\
\hline Troponin level, day 1 & 1.1 & $8.9-1.3$ & 4.046 \\
Troponin level, day 2 & 1.1 & $9.4-1.3$ & 2.189 \\
Troponin level, day 3 & 1.1 & $0.9-1.4$ & 0.219 \\
Days on mechanical ventilation & 1.0 & $0.9-1.0$ & 0.542 \\
Renal replacement therapy & 1.4 & $0.3-7.0$ & 0.668 \\
Lower limb ischaemia & 2.7 & $0.4-18$ & 0.278 \\
Positive blood culture & 0.04 & $0.003-0.5$ & 0.008 \\
Pleural cavity drainage & 0.2 & $0.02-2.3$ & 0.172 \\
\hline
\end{tabular}

$\mathrm{Cl}$ - confidence interval; OR — odds ratio

complications. No significant correlation was however observed between these complications and mortality.

Survival data presented herein is consistent with reports from literature. Data from the ELSO registry showed survival rate of $39 \%$ in patients having cardiogenic shock [4]. Similar results were reported by Aissaoui et al. [21], Sakamoto et al. [22], and authors of many other case series or smaller studies. In the presented study, 28\% patients had positive blood cultures. Impact of infection on results of ECMO therapy is controversial. Some authors suggest that sepsis or nosocomial infection correlate with risk of patient death $[23,24]$ whereas other reported no such link $[25,26]$. Patients surviving ECMO therapy are significantly longer hospitalised and spend more time in ICU. Duration of the latter in-hospital stay poses a particular infection risk.

\section{Limitations of the study}

Several limitations of the study need to be pointed out. The study had retrospective character, and was based on data retrieved from medical journals. Besides, patient group was small, therefore conclusions on statistically significant correlations should be treated with caution.

\section{CONCLUSIONS}

Successful ECMO therapy is based on close cooperation between anaesthesiologists, intensive care specialists, cardiac surgeons, perfusionists, pharmacologists and an experienced nursing staff. Therapy with VA ECMO may be successfully applied in severe cardiogenic shock, when conventional treatment is ineffective.

\section{Conflict of interest: none declared}

\section{References}

1. Pae WE Jr, Miller CA, Matthews Y et al. Ventricular assist devices for postcardiotomy shock. J Thorac Cardiovasc Surg, 1992; 104: 541.

2. Gibbon JH. Artificial maintenance of life during experimental occlusion of the pulmonary artery followed by survival. Surgery, Gynecol Obstetrics, 1939; 69: 602-614.

3. Hill DJ, O’Brien TG, Murray JJ. Prolonged extracorporeal oxygenation for acute posttraumatic respiratory failure (shock-lung syndrome). Use of Bramson membrane lung. N Engl J Med, 1972; 286: 629-634.

4. Extracorporeal Life Support Organization: http://www.elsonet.org.

5. Brown DJ, Brugger H, Boyd J et al. Accidental hypothermia. N Engl J Med, 2012; 367: 1930-1938.

6. Durrer B, Brugger H, Syme D. The medical on-site treatment of hypothermia ICAR-MEDCOM recommendation. High Alt Med Biol, 2003; 4: 99-100.

7. Soar J, Perkins GD, Abbas G et al. European Resuscitation Council Guidelines for Resuscitation 2010 Section 8. Cardiac arrest in special circumstances: Electrolyte abnormalities, poisoning, 
drowning, accidental hypothermia, hyperthermia, asthma, anaphylaxis, cardiac surgery, trauma, pregnancy, electrocution. Resuscitation, 2010; 81: 1400-1433.

8. Wanscher M, Agersnap L, Ravn J et al. Outcome of accidental hypothermia with or without circulatory arrest: experience from the Danish Praesto Fjord boating accident. Resuscitation, 2012; 83: 1078-1084.

9. Ruttmann E, Weissenbacher A, Ulmer H et al. Prolonged extracorporeal membrane oxygenation-assisted support provides improved survival in hypothermic patients with cardiocirculatory arrest. J Thorac Cardiovasc Surg, 2007; 134: 594-600.

10. Scaife ER, Connors RC, Morris SE et al. An established extracorporeal membrane oxygenation protocol promotes survival in extreme hypothermia. J Pediatr Surg, 2007; 42: 2012-2016.

11. Hagiwara S, Yamada T, Furukawa K et al. Survival after 385 min of cardiopulmonary resuscitation with extracorporeal membrane oxygenation and rewarming with haemodialysis for hypothermic cardiac arrest. Resuscitation, 2011; 82: 790-791.

12. Boue $Y$, Lavolaine J, Bouzat $P$ et al. Neurologic recovery from profound accidental hypothermia after 5 hours of cardiopulmonary resuscitation. Crit Care Med, 2014; 42: 167-170.

13. Morley D., Yamane K. O'Malley R et al Rewarming for accidental hypothermia in an urban medical center using extracorporeal membrane oxygenatio. Am J Case Rep, 2013; 14: 6-9.

14. Daubin C, Lehoux P, Ivascau C et al. Extracorporeal life support in severe drug intoxication: a retrospective cohort study of seventeen cases. Crit Care, 2009; 13: R138. doi: 10.1186/cc8017.

15. Wheeler TM, Baker JN, Chad DA et al. Case Records of the Massachusetts General Hospital. Case 30-2015: a 50-year-old man with cardiogenic shock. NEngl J Med, 2015; 373: 1251-1261. doi: 10.1056/NEJMcpc1415169.

16. Byrne J, Leacche M, Unie D et al. Staged initial percutaneous coronary intervention followed by valve surgery ("hybrid ap- proach") for patients with complex coronary and valve disease. J Am Coll Cardiol, 2005; 45: 14-18.

17. Goolsby MJ. National Kidney Foundation Guidelines for chronic kidney disease: evaluation, classification, and stratification. J Am Acad Nurse Pract, 2002; 14: 238-242.

18. Stanisz A. Przystępny kurs statystyki z zastosowaniem STATISTICA PL na przykładach z medycyny. Wydawca: StatSoft Polska, Kraków, 2007.

19. Musiał R, Darocha T, Kosiński S et al. Application of V-A ECMO therapies for short-term mechanical circulatory support in patients with cardiogenic shock. Anaesthesiol Intens Therapy, 2015; 47: 324-327. doi: 10.5603/AIT.2015.0046.

20. Aubron C, Cheng AC, Pilcher D et al. Factors associated with outcomes of patients on extracorporeal membrane oxygenation support: a 5-year cohort study. Crit Care, 2013; 17: R73.

21. Aissaoui N, Luyt Ch-E, Leprince $P$ et al. Predictors of successful extracorporeal membrane oxygenation (ECMO) weaning after assistance for refractory cardiogenic shock. Intensive Care Med, 2011; 37: 1738-1745. doi: 10.1007/s00134-011-2358-2.

22. Sakamoto S, Taniguchi N, Nakajima S, Takahashi A. Extracorporeal life support for cardiogenic shock or cardiac arrest due to acute coronary syndrome. Ann Thorac Surg, 2012; 94: 1-7.

23. Kumar TK, Zurakowski D, Dalton H et.al. Extracorporeal membrane oxygenation in postcardiotomy patients: factors influencing outcome. J Thorac Cardiovasc Surg, 2010; 140: 330-336.

24. Steiner CK, Stewart DL, Bond SJ et al. Predictors of acquiring a nosocomial bloodstream infection on extracorporeal membrane oxygenation. J Pediatr Surg, 2001; 36: 487-492.

25. Hsu MS, Chiu KM, Huang YT et al. Risk factors for nosocomial infection during extracorporeal membrane oxygenation. J Hosp Infect, 2009; 73: 210-216.

26. Sun HY, Ko WJ, Tsai PR et al. Infections occurring during extracorporeal membrane oxygenation use in adult patients. J Thorac Cardiovasc Surg, 2010; 140: 1125-1132.

Cite this article as: Musiał R, Moncznik P, Śmiałek P et al. Veno-arterial extracorporeal membrane oxygenation for short-term mechanical circulation support in adults with cardiogenic shock: a single centre experience. Kardiol Pol, 2016; 74: 1477-1484. doi: 10.5603/KP.a2016.0087. 


\title{
Doświadczenia własne w stosowaniu terapii za pomocą VA ECMO jako krótkoterminowego mechanicznego wspomagania krążenia u dorosłych pacjentów we wstrząsie kardiogennym
}

\author{
Robert Musiał ${ }^{1}$, Paweł Moncznik ${ }^{1}$, Paweł Śmiałek ${ }^{2}$, Jarosław Stoliński ${ }^{3}$, Jerzy Sadowski ${ }^{3}$, Rafał Drwiła ${ }^{4}$ \\ 'Oddział Anestezjologii i Intensywnej Terapii Medycznej, Krakowski Szpital Specjalistyczny im. Jana Pawła II, Kraków \\ ${ }^{2}$ Warszawski Uniwersytet Medyczny, Warszawa \\ ${ }^{3}$ Klinika Chirurgii Serca, Naczyń i Transplantologii, Uniwersytet Jagielloński, Krakowski Szpital Specjalistyczny im. Jana Pawła II, Kraków \\ ${ }^{4}$ Oddział Anestezjologii i Intensywnej Terapii Medycznej, Uniwersytet Jagielloński, Krakowski Szpital Specjalistyczny im. Jana Pawła II, Kraków
}

\section{Streszczenie}

Wstęp: Pacjenci we wstrząsie kardiogennym, nieodpowiadający na konwencjonalną terapię, mogą uzyskać wiele korzyści z leczenia za pomocą systemów wspomagających, takich jak membranowe natlenianie pozaustrojowe ECMO (extracorporeal membrane oxygenation), które zapewniają utrzymanie przepływów w krążeniu systemowym i/lub płucnym, odbarczając serce. Autorzy przedstawili doświadczenia własne w kwalifikowaniu i prowadzeniu terapii chorych we wstrząsie kardiogennym, u których zastosowano ECMO w konfiguracji żylno-tętniczej (VA ECMO).

Cel: Głównym celem badania było przeprowadzenie analizy czynników wpływających na przeżycie osób leczonych VA ECMO. Porównano grupę pacjentów, którzy przeżyli terapię ( $n=12 ; 41 \%)$, z grupą chorych, którzy zmarli mimo zastosowania VA ECMO.

Metody: Analiza retrospektywna dotyczyła pacjentów leczonych w okresie od lutego 2009 r., kiedy pierwszy raz zastosowano terapię ECMO w klinice autorów, do marca 2015 r. Badana populacja objęła 29 chorych leczonych za pomocą VA ECMO. Średni wiek pacjentów wynosił 42 lata; 19 osób stanowili mężczyźni (66\%). Do badania włączono wszystkich kolejnych chorych, leczonych w ośrodku autorów, znajdujących się we wstrząsie kardiogennym, u których zastosowano VA ECMO jako układ wspomagający pracę płuc.

Wyniki: Całkowita szpitalna śmiertelność wynosiła 59\% (17/29). Nie wykazano różnic między grupą zmarłych a grupą osób, które przeżyły, w odniesieniu do wieku, płci, wzrostu, trybu przyjęcia, chorób towarzyszących czy wartości frakcji wyrzutowej lewej komory ocenianej przy przyjęciu do szpitala. Analizie poddano liczbę dni leczenia za pomocą VA ECMO, stężenie troponin w pierwszych dobach wdrożenia terapii, przetoczenia koncentratu krwinek płytkowych, czas wentylacji mechanicznej. Nie wykazano istotnych różnic w obu grupach. Znamiennie dłuższy okazał się zarówno czas pobytu chorych na oddziale intensywnej terapii $(p=0,03)$, jak i czas pobytu w szpitalu $(p=0,016)$ w grupie pacjentów, którzy przeżyli.

Wnioski: Terapia za pomocą VA ECMO jest akceptowalną formą leczenia pacjentów w ciężkim wstrząsie kardiogennym. Szpitalna śmiertelność osób poddanych VA ECMO w niniejszym badaniu wynosiła 59\%. Oznacza to, że u 12 (41\%) chorych, u których wystąpił ciężki wstrząs kardiogenny, z powodzeniem zastosowano membranowe natlenianie pozaustrojowe.

Słowa kluczowe: wstrząs kardiogenny, membranowe natlenianie pozaustrojowe, pozaustrojowe wspomaganie funkcji życiowych 